
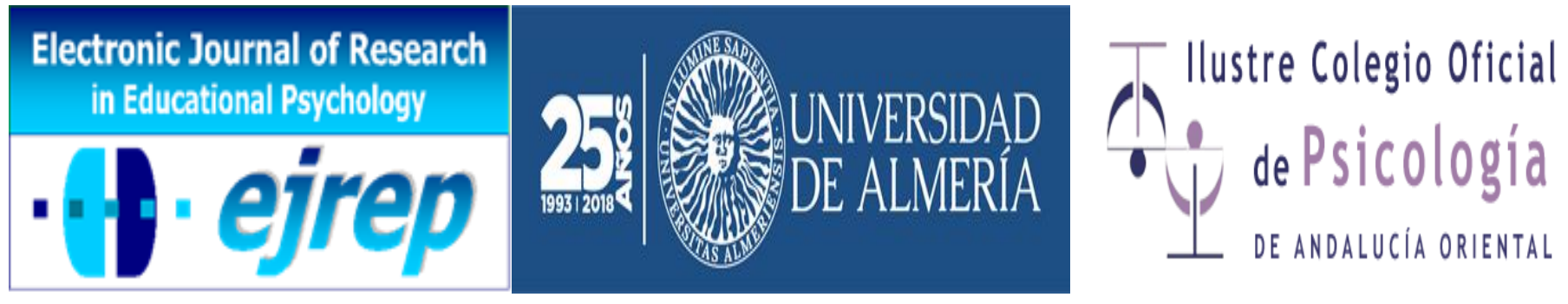

\title{
Strengthening of Reasoning Levels in higher education students through the use of Learning Strategies (Problem-Based Learning and Col- laborative Learning) Using ICT's
}

\section{Brigitte Julieth Rodriguez Mendoza, Martha Melizza Or- doñez Diaz ${ }^{2}$, Luis Carlos Meneses Silva ${ }^{3}$}

${ }^{1}$ Virtual education department, Manuela Beltrán University, Bogotá ${ }^{2}$ Virtual education department, Manuela Beltrán University, Bogotá

${ }^{3}$ Faculty of Engineering, Piloto University of Colombia, Bogotá

\section{Colombia}

Correspondence: Brigitte Julieth Rodriguez Mendoza, Centro Chía km 2 vía Cajicá, Cundinamarca. Colombia. E-mail: brigitte.rodriguez@umb.edu.co 


\begin{abstract}
Introduction. In the educational context, information and communication technologies imply a paradigm shift in learning-teaching processes both in the renewal of knowledge and practices and in evaluating knowledge appropriation. In this sense, in the present paper we analyze the incidence of the implementation of didactic strategies, problem-based learning (PBL) and collaborative learning (CL) in the strengthening of reasoning levels through the integration of technology to higher education.
\end{abstract}

Method. This research presents a quantitative approach and a quasi-experimental design in which 35 students of the "Colegio Mayor de Cundinamarca" (Bogotá, Colombia) participated: they were given a pre and a post-test using the Lawson's Classroom Test of Scientific Reasoning.

Results. With the collected information and after performing a descriptive statistical analysis it is possible to affirm that an $85.29 \%$ of total students are still at concrete reasoning level. However, those students that participated in the didactic strategy of PBL showed improvement in their reasoning level, going from concrete reasoning level to formal and post-formal level.

Conclusion. The results obtained allow us to conclude that there is no statistically significant difference in the improvement of the reasoning skills before and after the application of the didactic strategies, since when comparing students reasoning it is evident that most of them are still in the concrete reasoning level, that is, they remain linked to an empirical reality with a pre-operational thinking.

Keywords: problem-based learning, collaborative learning, information and communications technologies, Lawson's Classroom Test of Scientific Reasoning. 


\section{Resumen}

Introducción. En el contexto educativo, las tecnologías de la información y la comunicación (TIC) implican un cambio de paradigma en los procesos de enseñanza-aprendizaje, tanto en la renovación de las prácticas y contenidos, como en la manera de evaluar la apropiación de los conocimientos. En este sentido, en la presente investigación se analiza la incidencia que tiene la implementación de las estrategias didácticas, Aprendizaje Basado en Problemas (ABP) y Aprendizaje Colaborativo (AC) en el fortalecimiento de los niveles de razonamiento, a través de la integración de la tecnología a la educación superior.

Método. La investigación presenta enfoque cuantitativo, con diseño cuasiexperimental en la cual participaron 35 estudiantes de la Universidad Colegio Mayor de Cundinamarca en Bogotá - Colombia, a quienes se les aplicó un pre y un post test, usando el Lawson’s Classroom Test of Scientific Reasoning

Resultados. Con la información obtenida y al realizar un análisis estadístico descriptivo es posible afirmar que un $85.29 \%$ del total de estudiantes aún se encuentran en el nivel de razonamiento concreto, sin embargo aquellos estudiantes que participaron en la estrategia didáctica de ABP presentaron una mejora en su nivel de razonamiento, pasando del nivel de razonamiento concreto al nivel formal y post-formal.

Conclusiones. Los resultados obtenidos permiten concluir que no existe una diferencia estadísticamente significativa en la mejora de las habilidades de razonamiento antes y después de la aplicación de las estrategias didácticas, ya que al comparar el razonamiento de los estudiantes se evidencia que en su mayoría aún se encuentran en el nivel de razonamiento concreto, es decir, que permanecen ligados a una realidad empírica con un pensamiento pre-operacional.

Palabras Clave: aprendizaje basado en problemas, aprendizaje colaborativo, tecnologías de la información y comunicación, prueba de Lawson. 


\section{Introduction}

ICT-based education allows for the establishment of information culture through the construction of knowledge development scenarios that demand from the teacher the design and implementation of innovative didactical activities that transform knowledge culture and information into a significant learning process. According to Guzman (2014, p. 10): "The expectations in the educational field- regarding the implementation of ICT's in learning and teaching processes- are very high due to the potential they have to transform them. These changes have led to those responsible for education on a national level and directors on an institutional level to implement different plans and projects that guide educational institution in an ICT-integration process in order to enrich the institution in organizational, communicative, pedagogical and technological areas".

Accordingly, it is precise to state that the learning-teaching process supported by the use of ICT's is an imperative necessity in classrooms as it allows building context-related knowledge; cognitive, motivational and attitudinal dimensions, which will allow for an impact in society and knowledge construction. However, it is impossible to deny that the use of technological tools will enrich teaching processes even more through processes that involve detailed planning in terms of learning objectives, context analysis and results monitoring.

In this sense, the University school center promotes the use of ICT's in the classroom through the Educational Innovation System supported on ICT's, “(a) project responsible of incorporating virtual methodology in teaching-learning processes, and which is also in charge of giving advisory, support and technical help" (SIETIC, 2015). Accordingly, the authors of the present research paper have the main objective of implementing -in the Computer Workshop of the academic program "Technology in Architecture and Engineering Designers" in presence-based modality- teaching processes enabled by ICT's in order to strengthen reasoning levels in the students under the execution of PBL and CL didactic learning strategies through virtual learning activities supported in the use of digital resources with pedagogical and communication qualities that can influence the research purpose.

The main purpose of this research lies in how important it is for man not just to acquire knowledge but to transform and communicate it, so that it becomes an argument shared through social activities that take place within specific communities (Simon, Erduran and Os- 
borne, 2006), which can be developed through both virtual and physical meetings, a response to the changes that have happened all over society especially in education, where normal teaching must adapt itself to new challenges that are currently being tackled with virtual education: a new technology that promotes a collaborative learning-teaching scheme in which the student is an active protagonist of his own training and the teacher moves to a role of efficient counselor through the effective use of didactic strategies and technological resources that enable significant learning through the use of ICT's and education.

Thanks to the encounter of experiences, reasoning and communication the learning and teaching process is born, which is shared through strategies in the classroom as organized, determined and proposed procedures to reach the goals established in this space and as an answer to diverse needs of the social environment: this is why it is ideal that teachers implement didactical learning-teaching strategies in which their students are involved (Miguez, 2005), and whose class development is not just theoretical but also promotes the application of useful learning techniques for daily life, using pragmatic and professional development terms, and with the help of the dynamics present in science and technology.

For the development of a class session, the teacher must select learning theories and didactical methodologies that allow him to create a teaching strategy in accordance with activities, moments and established topics but it is also necessary to lay out its structure as a social space so as to facilitate critical thought, creativity and a complete evaluation of the used strategies: all of this with the objective of contributing to the construction of a knowledge-based society.

Based in this previous statement, the present research paper performs an analysis on two didactical strategies: PBL and CL, implemented through virtual tools in the classroom of the computer workshop course so as to establish which is the strategy that has the most repercussion in strengthening reasoning levels in two groups composed by 35 first semester students, with the same academic traits.

\section{The Rationale}

According to Giere's studies (1994), rationale is a logical process that demonstrates the coherence of argumentation, which in turn is based on premises that are analyzed to make 
decisions and at the end are made public and expressed in a social medium. Rationale, which to Peña (1993) depends on factual and schemed content, is made part of the cognitive structures of the person to build new knowledge which will help establish logical structures that are directly involved in the educational process -in turn involving teaching methods-, hoping they can foster critical analysis in students, forming thoughts that raise solutions to problems in their daily lives.

In order to achieve these goals, the teacher must find the way to focus his curricular contents in the development of cognitive and social skills (García de Cajén, García-Rodeja, \& Dominguez, 2002) that foster reasoning so that the student is an active participant in his own learning process. Regarding this; and in order to perform a development of scientific reasoning; Raviolo, Siracusa, Herbel and Schnersch (2000) propose that teachers must be in constant updating of their knowledge so that they can perform strategy formulation and organization thus enabling students to pay attention, code, transform, prove, store and locate the information they need in any situation.

Regarding the use of ICT's, the teacher's intervention in the strengthening of rationale in his students becomes more challenging since the construction of a significant learning experience and fostering of critical analysis in students must be done through virtual learning tools destined for the development of critical, innovative and creative attitudes as well as creating strategies that involve students in debates on current issues and real problems, challenging them to write their opinions, comments and suggestions through the mediums and tools given by the ICT's. The teacher must encourage the exploration of information sources from different authors and currents of thought, so that the students will not limit Themselves to the mere revision of the designated sources and literature but they'll provide debate opportunities and a wide interaction of different students, going as far as to enrich the debate with the participation of well informed authorities (using the means given by the ICT's themselves) and perform timely orientation, follow-up and feedback in order to keep student motivation high.

\section{Problem-Based Learning}

Problem-based learning is a technique or method that focuses on learning, research and critical reflection in order to find solutions to a problem proposed by the teacher (Gómez, 2005). The teacher provides subject content of the course in progress, later giving the students activities where they can apply such information for the students to turn into useful output 
based on the interaction with the study situation. Barrows (1986, p. 183) defines PBL as "a learning method based on the principle of using problems as a starting point for the acquisition and integration of new knowledge". When using this learning technique, the main performers are the students themselves, as they take the responsibility of being an active parttaker in the teaching-learning process. Prieto (2006) states, that "PBL represents an effective and flexible strategy that, based on what students do, can improve the quality of their learning in several aspects".

In order to work on the model there are no specific steps, but most authors agree on basic components that vary depending on the number of students, objectives, available information, resources and other related variables. The suggested route to work on PBL can be summarized in the following operations: 1) Read and analyse the problem scenario, 2) Brainstorm, 3) Make a list of what you know, don't know and what needs to be done to solve the problem, 4) Define the problem, 5) Obtain information, and 6) Present and deliver results (see Figure B1).

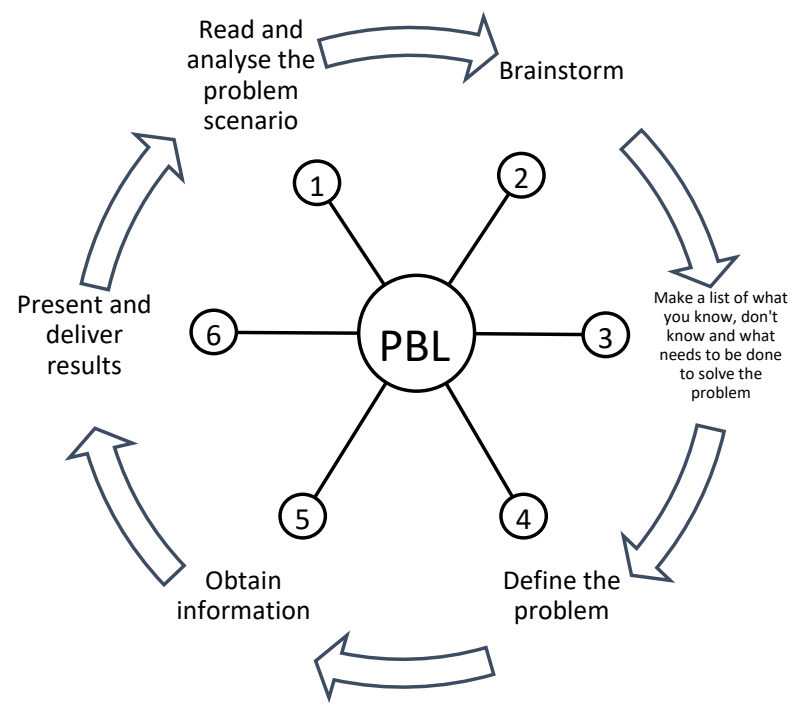

Figure B1. Suggested route to work in PBL. Retrieved from: Morales and Landa, 2004. P. 154.

According to the foregoing and what is showing in the figure B1, PBL enables students to develop and work on diverse skills. Among them we can highlight as follows:

\section{Problem resolution}

2. Decision-making

3. Teamwork 
4. Communication and argument development

5. Attitude and value development.

For the present research, this learning technique is not only applicable and seen in the classroom also in virtual academic contexts in which the ICT's have a fundamental role since communication, registration and presentation of information tools allow technology to be a support in finding solutions to targeted problems, as well as planning strategies that enable developing self-evaluation and self-assessment skills, among other qualities.

As aforementioned, the ICT environment offers tools that facilitate information revision, selection and evaluation found on the internet. This provides solutions to the problems found in the proposed scenarios; so that finding and selecting information sources -written, oral and visual- for their analysis and subsequent application to the PBL turns out to be a specific objective in the realm of ICT's (De La Vega, 2010, p.8). When choosing browsers and search engines, depending on the subject to deal with, it can generate strategies that as a whole can foster abilities in the competences linked to ICT's and PBL.

\section{Collaborative Learning}

Collaborative Learning is defined as "a carefully designed interactions system that organizes and induces reciprocal influences between members of a team" (Martínez, Catalá, \& Díaz, 2013), where they feel reciprocally committed with their own learning and that of others: this methodology involves teachers, students, didactical activities and tools to solve the latter.

To achieve learning, the teacher must use group work methodologies that enable the interaction of different team members, whose objective is knowledge appropriation and construction of new ideas and learning experiences. The development of CL allows for the sharing experiences and knowledge, and the search for common goals as well as the way to reach them so that they can arrive to the necessary conclusion and implement the project. The teacher that uses this work technique must design activities where target goals are clearly defined, as well as the materials and formation tools to be used (Collazos, \& Mendoza, 2006). 
In this type of learning, students can generate internal roles to carry out controls and delegate responsibilities regarding competence development and the achievement of necessary results: therefore, sometimes the role of the teacher can be reduced in order for student teams to take control of the class as they are in charge of defining the ways in which to reach the objectives set through techniques properly defined by each team. Thus, collaborative work is not limited to an academic environment as it allows the workgroup to share personal experiences and be a real support for each other'sintegral growth (Calzadilla, 2002). It must be noted that this technique is not group work but rather the sharing of individual experiences and skills that can solve projects determined by the teacher as well promote motivation for the achievement.

According to the above, in collaborative learning it is possible to form an interaction between three key issues in the teaching-learning process: collaboration, learning and strengthening of social networks both in real life and in virtual scenarios. Which produces interesting opportunities at an individual and group scale, as shown in the research by Lavigne, Vasconcelo, organist and McNally (2012), whose subject of study was the utility in forum use for the construction of knowledge in virtual collaborative learning. In this investigation, an exploratory analysis took place by looking at the navigation history in the Moodle platform used by 23 Masters students in the Autonomous University of Baja California during 2009 and who employed the forums as a learning tool: it was possible to conclude that, in spite of statistical analysis, the use of forums fostered the development of collaborative learning as well as relationship consolidation between classmates.

Therefore, it is necessary that the teacher assumes the use of ICT's as a support tool in the teaching-learning process: a process in which digital tools make it possible to implement innovative didactical strategies to involve the student and immerse him or her in collective learning processes by joining them in the learning process withtheir peers. This transforms the traditional role of the teacher -sole bearer of knowledge- and creates study groups where the collaborative characteristic is key to learn: thus, those who are part of the group learn by expressing their questions, participating in knowledge networks, teaching each other and exchanging wisdom not just personally but through virtual resources that give access to different information sources, building knowledge and debating stances on a topic. The teacher then 
becomes an adviser that fosters communication, interaction with information, students internalizing knowledge and knowledge application in real or simulated environments.

Contrary to what was assumed at the end of the nineties, education supported by ICT's is not just useful for distance learning: rather, it is a pedagogical tool that complements classroom education by improving communication skills through the use of synchronous learning and communication tools (audio conference, chats and video conferences) and asynchronous tools (e-mail, videos, simulators, video games, multimedia, forums, blogs, knowledge networks, online libraries, tests, etc.). Virtual learning is a strategy that seeks to promote training spaces with the help of ICT's in order to create a new way of teaching and learning.

In conclusion, we can affirm that PBL and CL learning strategies that are supported by ICT's develop effective and creative reasoning skills as they generate knowledge contributions to group reasoning process and offer argumentation of solid ideas. The learning process is complemented with the use of virtual learning tools whose network environment makes it easier -through the use of multiple communication resources, both synchronous and asynchronous- to exchange knowledge as well as student-teacher and student-student interactions. These two learning-teaching methodologies compromise and motivate students in the development of class topics, as evidenced in Tarazona's (2005) study, when implementing PBL strategies in medical training and in the qualitative analysis of Scagnoli (2005), after revising collaborative learning situations in distance learning classes among several universities: all of this allows us to observe that these strategies stimulate habits of thought development in order to generate significant learning and enable an improvement in study skills, creating in turn problem-solving skills through reasoning and argumentation.

\section{Problem Definition}

During the last 30 years, the learning/teaching processes have changed significantly, going from a behavioral model in a regular classroom in which the teacher was the only voice and knowledge transmitter to a student-centered education, who actively participates in knowledge construction and can develop his learning processes in a virtual and/or regular context. This ends up making the teacher an adviser in the learning process by solving the student's questions, becoming a facilitator of the information to be used during the development of theclass and motivating students in comprehension, appropriation and application of 
the knowledge seen in the classroom: in addition, he complements the learning/teaching process with digital resources for achieving goals that are part of the curricular activities.

However, and even in first term students of the academic program "Technology in Architecture and Engineering Designers", we can see in the Computing Workshop a passive stance, just waiting for master classes based on the verbal exposition of the teacher and towards which there are no critical analysis nor experience based contributions: on the contrary, there is a one-way communication from the teacher towards the students. In addition, the interest pertaining computer use on behalf of the student is based on managing office applications - for this reason we deem it necessary; through the present research; to implement through the use of ICT's PBL and CL learning strategies that strengthen students' rational so that it is possible to have classes that develop argumentative competences in the students, generating reasoning towards the topics dealt by the teacher, the conception of ideas in the group to support proposals exposed by other class participants and the creation of knowledge networks that transcend through the use of digital learning tools.

Taking into account that students are not familiar with the development of formal reasoning patterns, Lawson (2008) states that the teacher must impart knowledge in scientific areas and give self-regulation guidelines to each student in order to achieve an internal intellectual development that reflects on his own thoughts and the thoughts of others using learning environments where everyone's ideas are exposed: .The teacher, acting as an adviser, must find ways so that the argument is a process weaved into the dialogue through context rationale (Rapanta, García, \& Gilabert, 2013) and give them reflective language that demonstrates if their statements are correct or not. In order to make progress in this area, it is necessary that the teacher does some research in order to design learning activities and sections that favor teachings of his area of expertise in the rationale framework.

Taking this and what was exposed as problem into account, we pose the following question: Does the implementation of didactical learning strategies (PBL and CL) supported in information and communication technologies (ICT's) generate a change in the rationale levels of higher education students? 


\section{Method}

\section{Participants}

The present investigation is done under a quantitative approach and a quasiexperimental design with a representative sample, non-random and without a control group as all the 35 students that participated in the investigation are enrolled in the Computer Workshop course, part of the first semester of the "Technology in Architecture and Engineering Designers" program, night shift, of the University Colegio Mayor de Cundinamarca in the city of Bogotá, making them comparable populations. The students were organized into two courses labeled by the Engineering Faculty as Group A and Group B, with 18 and 17 students each, whose ages fluctuated between 17 and 45, with different academic levels and of lowmiddle income, according to Law 142 of 1994 in Colombia.

The Computer Workshop course takes place in a technology lab in the Engineering and Architecture Faculty, furnished with computing equipment for each student. For the development of this investigation, the authors initially worked with the Edmodo platform (https://www.edmodo.com) and later with the academic platform of the University, Moodle (http://presencial.unicolmayor.edu.co): in these virtual surroundings, the teacher socializes the program of each one of the virtual learning activities the students must complete and, for master classes, the teacher has a 52" LG Pentouch Smart TV Interactive Board. The curricular content of the class is focused on explaining the use of technological tools through master classes in which the student individually must complete a series of instructions given by the teacher in order to develop the class activities that evaluate the knowledge and skills he has acquired in the classroom.

\section{Procedure}

With the purpose of studying the incidence the implementation of didactical strategies such as PBL and CL have in the strengthening of rationale levels through the integration of technology in higher learning; we took into account the development of the stages shown in Figure B2 and and defined below: 


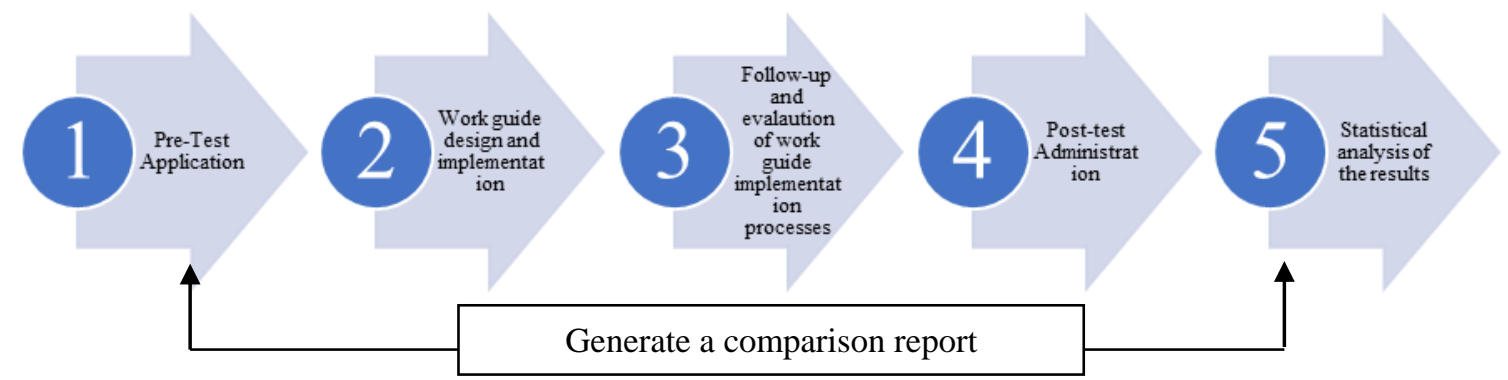

Figure B2. Central phases of the investigation

\section{Pre-test Application}

Initially, a pre-test is given to the 35 students on specific abilities in order to identify the rationale level on basic logic and critical analysis issues, and the Lawson's Classroom Test of Scientific Reasoning was applied (LCTSR), considered as a "valid and reliable instrument that measures the levels of formal scientific reasoning in students of different ages and academic backgrounds" (Thoron \& Myers, 2012, p.158).

\section{Instruemnts}

The LCTSR is composed of 24 questions that evaluate scientific and mathematical reasoning, whose answers are fed into an Excel spreadsheet and organized into pairs that are linked to the 12 types of rationale proposed by Lawson in order to determine the evaluated capacity (see Table A1), and where every type of reasoning is valid if two questions are correct. Later, the six rationale aspects are assessed according to the measured capacity (see Table A2). Based on these results the reasoning level of each group is determined. Finally, all the information is organized into three reasoning levels: concrete thought ( $0-4$ pairs), formal thought (between 6-9 pairs) and post-formal (more than 9).

Table A1. The 12 types of reasoning

\begin{tabular}{ccl}
\hline Number & Related questions & Evaluated Capacity \\
\hline $\mathbf{1}$ & $1-2$ & Weight conservation \\
$\mathbf{2}$ & $3-4$ & Conservation of the displaced volume \\
$\mathbf{3}$ & $5-6$ & Proportionality thought \\
$\mathbf{4}$ & $7-8$ & Advanced proportionality thought \\
$\mathbf{5}$ & $9-10$ & Variable control and identification \\
$\mathbf{6}$ & $11-12$ & Variable control and identification \\
$\mathbf{7}$ & $13-14$ & Variable control and identification, probabilistic thought \\
$\mathbf{8}$ & $15-16$ & Variable control and identification, probabilistic thought \\
$\mathbf{9}$ & $17-18$ & Probabilistically and proportional thought \\
$\mathbf{1 0}$ & $19-20$ & Probabilistically and proportional thought \\
\hline
\end{tabular}




\begin{tabular}{ccl}
\hline Number & Related questions & Evaluated Capacity \\
\hline $\mathbf{1 1}$ & $21-22$ & Combinatorial thought \\
$\mathbf{1 2}$ & $23-24$ & Correlational and probabilistically thought \\
\hline
\end{tabular}

Retrieved from: (Lawson, 1978)

Table A2. Six types of reasoning

\begin{tabular}{lll}
\hline No & Evaluated Capacity & Rationale Aspects \\
\hline 1 & $1-2$ & Conservation of physical dimensions (1 and 2), \\
2 & $3-4$ & Proportionality Rationale (3 and 4), \\
3 & $5-6-7$ & Variable identification and control (5, 6 and 7), \\
4 & $8-9$ & Probability rationale and combinatorial reasoning (8 and 9), \\
5 & 10 & oi \\
6 & $11-12$ & Hypothesis management (11 and 12) \\
\hline
\end{tabular}

Retrieved from: (Lawson, 1978)

\section{Work Guide Design and Implementation}

A total of 6 work guides were made for each group, taking into account the topics exposed in the curricular plan of the Computer Workshop course and in the framework of each one of the didactical learning strategies established for each group. According to the above, group A worked on PBL and group B worked on CL.

In each of the crafted work guides, the activities to be developed are described in detail, as well as the didactical learning strategy to be used and the results to be obtained, taking into account that the inclusion and use of technology stimulates mental processes making the learning/teaching act more significant so that the students can appropriate curricular references (Vence, no date). To the general proposal of learning activities, we add the pedagogical use of ICT's through the use of digital, interactive and dynamic tools the students must use for the development of each activity: this activity must be done with the permanent assistance and guidance of the tutor. Each guide contains: wo

- $\quad$ Title of the work guide.

- $\quad$ Objective (work methodology).

- Description of the activity (Work scenario).

- Technological resources.

- Work phases.

- $\quad$ Final product.

These previous items guide the students so that they investigate the topics mentioned in the curricular plan under the guidelines of the assigned learning strategy and using different 
digital learning tools. For this reason, the following learning activities were implemented in each group (see Table A3).

Table A3. Learning activities

\begin{tabular}{|c|c|c|c|c|}
\hline No. & Thematic Content & Resources & Objectives & $\begin{array}{l}\text { Activities } \\
\text { (Implementation) }\end{array}$ \\
\hline 0 & Pre-test & Digital Form & $\begin{array}{l}\text { Identify pre-knowledge } \\
\text { and the rationale level. }\end{array}$ & $\begin{array}{l}\text { Answer the } 24 \text { questions of } \\
\text { the LCTSR }\end{array}$ \\
\hline 1 & $\begin{array}{l}\text { Equipment history } \\
\text { of current computer } \\
\text { systems. }\end{array}$ & $\begin{array}{l}\text { Movie: Silicon Valley } \\
\text { pirates. Smart TV. } \\
\text { Academic Platform. } \\
\text { CmapTools. }\end{array}$ & $\begin{array}{l}\text { Introduce students in } \\
\text { the equipment history } \\
\text { of current computer } \\
\text { systems. }\end{array}$ & Cinema Forum \\
\hline 2 & $\begin{array}{l}\text { Basic concepts - } \\
\text { Hardware and Soft- } \\
\text { ware. } \\
\text { Social networks in } \\
\text { academic life. }\end{array}$ & $\begin{array}{l}\text { Digital bibliography. } \\
\text { Digital guides. Multi- } \\
\text { media presentations. } \\
\text { Academic platform. } \\
\text { Office software. } \\
\text { Videos and Internet. }\end{array}$ & $\begin{array}{l}\text { Understand basic } \\
\text { Hardware concepts. } \\
\text { Distinguish different } \\
\text { types of software: Op- } \\
\text { erative System and } \\
\text { Applications. } \\
\text { Describe the main } \\
\text { functions of an opera- } \\
\text { tive system. } \\
\text { Identify the most com- } \\
\text { mon apps to use them } \\
\text { in the solution of dif- } \\
\text { ferent types of tasks } \\
\text { and necessities. }\end{array}$ & $\begin{array}{l}\text { AC } \\
\text { Case Analysis } \\
\text { Through the } 8 \text { steps of ABP, } \\
\text { read and analyze the prob- } \\
\text { lem scenario. }\end{array}$ \\
\hline 3 & $\begin{array}{l}\text { Services offered by } \\
\text { Internet: e-mail, } \\
\text { search engines, } \\
\text { navigators. }\end{array}$ & $\begin{array}{l}\text { Cellphone. } \\
\text { YouTube } \\
\text { Academic platform. } \\
\text { Work guide. }\end{array}$ & $\begin{array}{l}\text { Identify basic concepts } \\
\text { of Internet use related } \\
\text { to professional activi- } \\
\text { ties and daily tasks. }\end{array}$ & $\begin{array}{l}\text { Make videos, news spot, } \\
\text { TopShow or another audio- } \\
\text { visual format. }\end{array}$ \\
\hline 4 & $\begin{array}{l}\text { Virtual groups. } \\
\text { Communication } \\
\text { tools (Video confer- } \\
\text { ences) }\end{array}$ & $\begin{array}{l}\text { Academic platform. } \\
\text { Support videos. Appli- } \\
\text { cation to generate in- } \\
\text { teractive content } \\
(\underline{w w w . g e n i a l . l y)}\end{array}$ & $\begin{array}{l}\text { Propose tools of virtual } \\
\text { communication that } \\
\text { favor development in } \\
\text { the academic groups. }\end{array}$ & $\begin{array}{l}\text { AC } \\
\text { Create a computer graphics. } \\
\text { ABP } \\
\text { Revise the case study, pre- } \\
\text { sent results in a computer } \\
\text { graphics with the collected } \\
\text { information. }\end{array}$ \\
\hline 5 & $\begin{array}{l}\text { Ergonomics in com- } \\
\text { puter use. }\end{array}$ & $\begin{array}{l}\text { Time Line. } \\
\text { Academic platform. } \\
\text { Search engines. Virtual } \\
\text { library. }\end{array}$ & $\begin{array}{l}\text { Comprehend the im- } \\
\text { portance of ergonomics } \\
\text { history in computer } \\
\text { use. }\end{array}$ & $\begin{array}{l}\text { AC } \\
\text { Deliver a time line in the } \\
\text { TimeLine program. } \\
\text { ABP } \\
\text { Evaluate the case study on } \\
\text { ergonomics in computing } \\
\text { taking into account ABP } \\
\text { analysis steps: } \\
\text { Resolution process of the } \\
\text { problem. } \\
\text { Information management. } \\
\text { Verbal and written commu- } \\
\text { nication. } \\
\text { Teamwork. }\end{array}$ \\
\hline 6 & $\begin{array}{l}\text { Cloud computing. } \\
\text { Cloud computing }\end{array}$ & $\begin{array}{l}\text { Cloud computing tools. } \\
\text { Search engines. }\end{array}$ & $\begin{array}{l}\text { Know and interpret the } \\
\text { main characteristics of }\end{array}$ & $\begin{array}{l}\mathrm{AC} \\
\text { Create a comparative chart }\end{array}$ \\
\hline
\end{tabular}


Brigitte Julieth Rodriguez Mendoza et al.

\begin{tabular}{|c|c|c|c|c|}
\hline No. & Thematic Content & Resources & Objectives & $\begin{array}{l}\text { Activities } \\
\text { (Implementation) }\end{array}$ \\
\hline & $\begin{array}{l}\text { characteristics. } \\
\text { Types of Cloud } \\
\text { Computing tools. }\end{array}$ & Virtual library. & cloud servers. & $\begin{array}{l}\text { in a Drive document. } \\
\text { ABP } \\
\text { Evaluate the case study } \\
\text { following the steps proposed } \\
\text { by the teacher. Present it } \\
\text { through the use of Cloud } \\
\text { Computing tools. }\end{array}$ \\
\hline 7 & Post-Test & 4. Digital Form & $\begin{array}{l}\text { Identify the advance of } \\
\text { the rationale test. }\end{array}$ & $\begin{array}{l}\text { Answer the } 24 \text { questions of } \\
\text { the LCTSR. }\end{array}$ \\
\hline
\end{tabular}

\section{Follow-up and Evaluation of Work Guide Implementation}

After each session, each work group hands in the finished work guide, which will be evaluated by the teacher. These results will be given as feedback to the students in the next session, sharing the knowledge of the curricular content in a group session, where each of the students actively participates to comment what was learned in the previous session.

\section{Post-Test Application}

A post-test will be administered to the 35 students, using the LCTSR as an instrument of gathering information under the conditions described in the first stage of the investigation, so as to evidence the incidence of learning strategies in the reasoning level of the students, before and after the implementation of learning activities.

\section{Data Analysis}

Based on the results obtained in the pre and post-test of each group, we perform statistical analysis through the application of the Student T test, which is defined as a parametric test that allows the comparison of the median in two similar groups and collate -in this casethe average rationale level in each group. To do this, two analyses are made, one for group A and one for group B where pre and post tests are compared in independent samples (comparison between both groups) and dependent samples (comparison within the same group).

\section{Results and discussion}

With the final results, it is clear that group A -those who received the instruction with the ABP strategy $\left(\mathrm{A}_{\mathrm{ABP}}\right)$, they scored in the post test an average of $(\mathrm{x}) 4.75$ and a standard deviation $(\sigma)$ of 4.69 in correct answers versus $\mathrm{x}=4.16$ and $\sigma=3.71$ in the pre-test (Table A4), which makes it clear that the standard deviation after administering the post-test has a 
lower bias: this means that after applying a didactical learning strategy the presence of extreme values diminishes, making the group a more homogenous population in their rationale levels. Group B, on the other hand, worked with the didactical learning strategy $A C,\left(B_{A C}\right)$, scoring $\mathrm{x}=2.58$ and $\sigma=3.42$ in the post test, with scores in the pre-test of $\mathrm{x}=4.08$ and $\sigma=$ 3.96 (Table A4), indicating that probably the bias, and the presence of extreme values or another peculiarity in the distribution, is higher after applying the post-test. This indicates that the second group has a higher variability in their rationale levels after applying the learning strategy.

Table A4. Descriptive Statistics or statistical parameters of the Lawson test - Group AABP and $B_{A C}$

\begin{tabular}{lcccc}
\hline Parameters & $\begin{array}{r}\text { Pre-test } \\
\text { Group A }\end{array}$ & $\begin{array}{c}\text { Post-test } \\
\text { Group A }\end{array}$ & $\begin{array}{c}\text { Pre-test } \\
\text { Group B }\end{array}$ & $\begin{array}{c}\text { Post-test } \\
\text { Group B }\end{array}$ \\
\hline Mean & 4,16 & 4,75 & 4,08 & 2,58 \\
Median & 3,5 & 2,5 & 3 & 1 \\
Mode & 1 & 2 & 0 & 0 \\
Standard Deviation & 3,71 & 4,69 & 3,964 & 3,42 \\
Range & 11 & 16 & 12 & 11 \\
Minimum & 0 & 0 & 0 & 0 \\
Maximum & 11 & 16 & 12 & 11 \\
Number of students & 12 & 12 & 12 & 12 \\
Confidence Level $(95,0 \%)$ & 2,3 & 2,9 & 2,5 & 2,1 \\
\hline
\end{tabular}

Taking into account the results of the 12 pairs of organized questions from the LCTSR that measure six rationale characteristics (Figure B3), as follows: 1. Conservation of physical values, 2. Proportionality rationale 3. Variable identification and control, 4. Probabilistic rationale, 5. Combinatorial reasoning and 6. Correlational rationale. The reagent ranking with correct answer percentage in the pre and post-test of the group $\mathrm{A}_{\mathrm{ABP}}$ and $\mathrm{B}_{\mathrm{AC}}$ is presented showing the following results:

a) Group $\mathrm{A}_{\mathrm{ABP}}$ showed an improvement in proportionality reasoning of $16.67 \%$; in variable identification and control, an improvement of $2.78 \%$; in probabilistic combinatorial reasoning, an improvement of $8.33 \%$ and in correlational rationale, an improvement of $2.78 \%$ (Figure B3, left side).

b) Group $\mathrm{B}_{\mathrm{AC}}$ decreased in the different evaluations. It did not show any evolution in improving variable control and identification, in probabilistic combinatorial reasoning and in correlational reasoning (Figure B3, right side). 

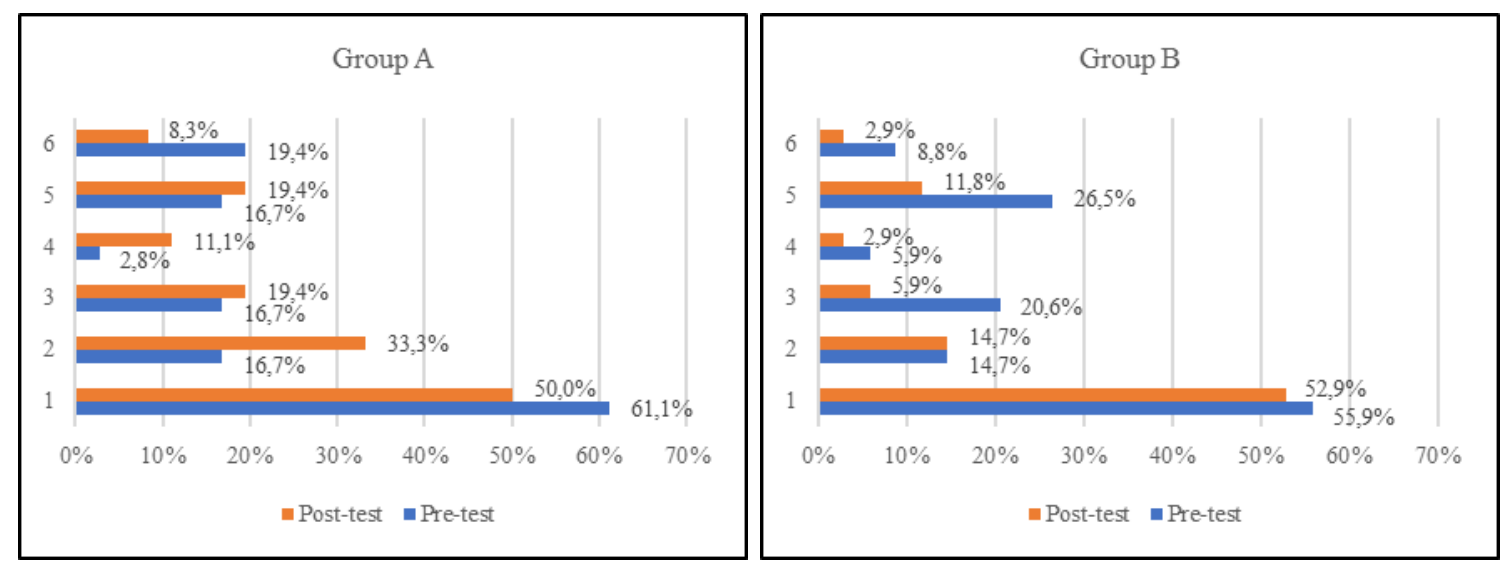

Figure B3. Classification of the six types of pre and post-test reasoning of the AABP (left) and $\mathrm{B}_{\mathrm{AC}}$ groups (right) based on correct answers.

This information allows to compare results through the Student's t-test. It can be stated that:

a) The results from the analysis performed between the $\mathrm{A}_{\mathrm{ABP}}$ pre-test and $\mathrm{B}_{\mathrm{AC}}$ show that there is no difference among them. Taking into account that, it can be said that the groups are comparable in the variable of scientific reasoning before the intervention (see Table A5). A valid comparison to evaluate the post-test in both groups can be made. This parity relationship between the groups can be clearly seen when reviewing the t-statistic and realizing that it is lower than the critical value of the two tails. That demonstrates that there is no statistically meaningful difference between the two groups. It can be clearly stated that they are homogenous or similar in this variable before the intervention.

Table A5. Descriptive Statistics or Statistical Parameters. Lawson pretest, Groups AABP and $B_{A C}$

\begin{tabular}{lcc}
\hline Statistical Parameters & Pre $\mathbf{A}_{\mathbf{A B P}}$ & Pre $\mathbf{B}_{\mathbf{A C}}$ \\
\hline Mean & 2,6 & 2,8 \\
Variance & 2,6 & 3,1 \\
Observations & 18 & 17 \\
T-statistic & $-0,3$ & \\
Critical value of T (two-tailed) & 2,0 & \\
\hline
\end{tabular}

b) After the application of didactical learning strategies, the results show that there is no statistically meaningful difference between the pre and post-test in the $\mathrm{A}_{\mathrm{ABP}}$ and $\mathrm{B}_{\mathrm{AC}}$ groups (Table A6). This can be stated because the t-statistic is lower than the critical 
value of two tails. Therefore, this allows to say that the intervention provoked positive changes in the group 'reasoning and argumentation.

Table A6. Descriptive statistics or statistical parameters. Lawson test, $A_{A B P}$ pre and post test

\begin{tabular}{lcc}
\hline Statistical Parameters & Pre A ABP & Post $\mathbf{A}_{\text {ABP }}$ \\
\hline Mean & 2,6 & 3,1 \\
Variance & 2,6 & 6,1 \\
Observations & 18 & 18 \\
T-statistic & $-0,9$ & \\
Critical value of T (two-tailed) & 2,1 & \\
\hline
\end{tabular}

c) After the application of the didactical strategy in the BAC group, it was possible to see a statistically significant difference between the group pre and post-test (Table A7), as the T-statistic is higher than the critical value of two tails. This allows to conclude that the intervention provoked negative changes for the group instead of showing an improvement. It also showed a setback in their reasoning and argumentation skills.

Table A7. Descriptive statistics or statistical parameters. Lawson test, BAC pre and post test

\begin{tabular}{lcc}
\hline Statistical Parameters & Pre $\mathbf{B}_{\mathbf{A C}}$ & Pre $\mathbf{B}_{\mathbf{A C}}$ \\
\hline Mean & 2,8 & 1,8 \\
Variance & 3,1 & 1,7 \\
Observations & 17 & 17 \\
T-statistic & 2,5 & \\
Critical value of T (two-tailed) & 2,1 & \\
\hline
\end{tabular}

d) When comparing the post-test for $\mathrm{A}_{\mathrm{ABP}}$ and $\mathrm{B}_{\mathrm{AC}}$, a statistically significant difference in one tail and the variations can be seen (Table A8). This evidence a violation to the ttest assumptions: therefore, it is necessary to use the $U$ parametrical methods of Mann Whitney to reject that the median in both groups is equal. This demonstrates that the groups possess a statistically significant difference (Tables A9 and A10).

Table A8. Reasoning aspects, Lawson test. Post-test, groups $A_{A B P}$ and $B_{A C}$

\begin{tabular}{lcc}
\hline Statistical Parameters & Post AABP & Post B $\mathbf{B}_{\mathbf{A C}}$ \\
\hline Mean & 3,1 & 1,8 \\
Variance & 6,1 & 1,7 \\
Observations & 18 & 17 \\
T-statistic & 1,9 & \\
Critical value of T (one tail) & 1,7 & \\
Critical value of T (two-tailed) & 2,0 & \\
\hline
\end{tabular}

Table A9. Ranks for A and B groups through a non-parametrical Mann-Whitney U method in post-test for groups $A_{A B P}$ and $B A C$ 
Brigitte Julieth Rodriguez Mendoza et al.

\begin{tabular}{lcccc}
\hline Test & Group & N & Mean Rank & Sum of Ranks \\
\hline \multirow{2}{*}{ Post } & A & 18 & 20.33 & 366 \\
& B & 17 & 15.53 & 264 \\
\hline
\end{tabular}

Table A10. Analysis through a non-parametrical Mann-Whitney $U$ method in post-test for groups $A_{A B P}$ and $B_{A C}$

\begin{tabular}{lc}
\hline Parameter & Post-test both gro \\
\hline Mann-Whitney U & 111.00 \\
Wilcoxon W & 264.00 \\
Z & -1.426 \\
Asymptotic significance (2-tailed) & 0.154 \\
Exact significance [2*(tailed significance)] & $0.173^{(*)}$
\end{tabular}

(*) Not corrected for tires. 
Finally, after getting the final results from LCTSR, the circular graph of reasoning levels was compared in order to evaluate the concrete, formal and post-formal reasoning levels of each group (Figures B4 and B5). It was demonstrated that:

a) About $22 \%$ of the students in the $\mathrm{A}_{\mathrm{ABP}}$ group reached a formal reasoning level and about $5,56 \%$ of the students advanced to a post formal level. This means that there was an evolution of concrete thought to higher reasoning levels through the application of the PBL strategy, improving variable control in $22.22 \%$ and proportionality and mass conservation in $27,78 \%$ (Figure B4). Thus, even if it was not a significant improvement, the qualities of this didactical learning strategy can improve reasoning. According to Branda's interventions (2013), PBL can combine and synthesize data into explanatory hypotheses of the problem and identify the principles and concepts that can be applied to other situations in order to get formal reasoning.

Pre-test

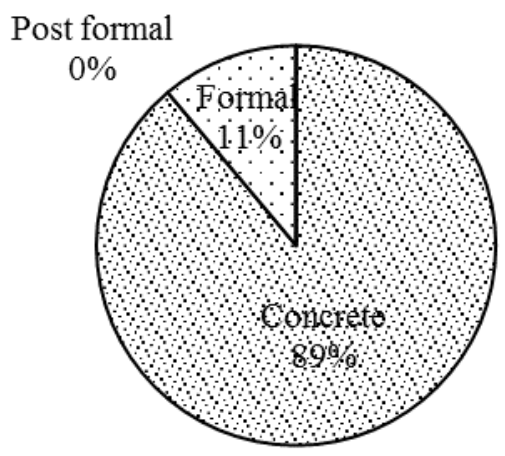

Post-test

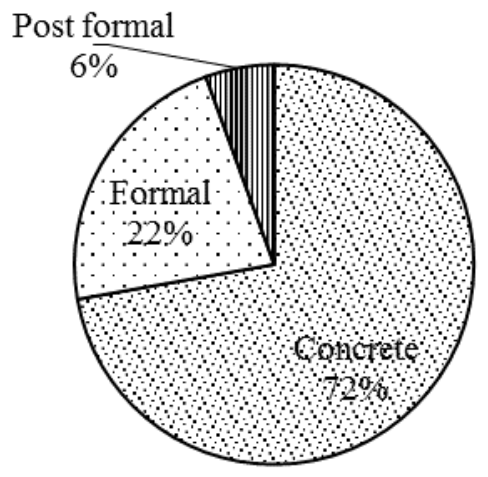

Figure B4. Circular graph of pre and post-test reasoning levels, $\mathrm{A}_{\mathrm{ABP}}$ group

b) In the group B of students (Figure B5), there was no improvement in their reasoning levels. On the contrary, there was a reduction in the number of students with formal reasoning, going from $24 \%$ to $6 \%$. In addition, there was an increase in the number of students with concrete reasoning levels, going from $76 \%$ to 94 . This could happen due to students' lack of motivation towards team work and little collaboration from some of them in some activities developed in the classroom, affecting the entire group performance. This situation, analyzed by Miguez (2005, p.3) is shown as "one of the main causes of deterioration and one of the most serious problems in learning, especially in formal education"

c) 

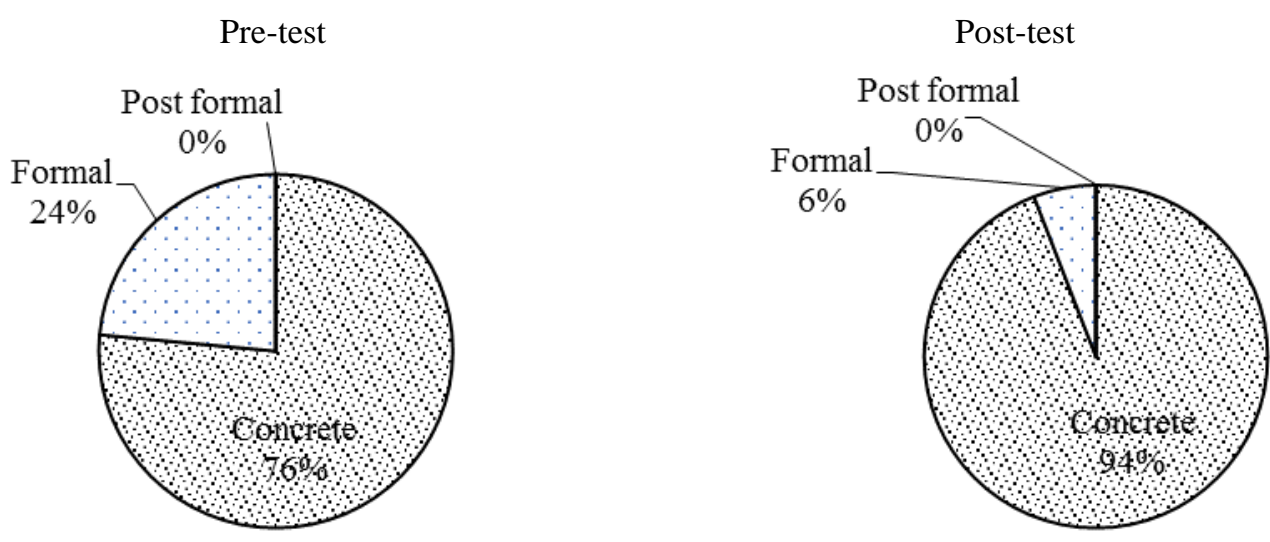

Figure B5. Circular graph of pre and post test reasoning levels, $\mathrm{B}_{\mathrm{AC}}$ group.

\section{Conclusions}

The results obtained after the application of the $\mathrm{T}$ test in the AABP group allow us to accept the hypothesis as null because the statistical value of $\mathrm{T}$ is lower than the critical value. That indicates that there are no statistically meaningful differences. In that case, we can establish that reasoning skills before and after applying the didactical learning strategy are similar and have no significant variation.

The work done in a two-hour class once a week and during one semester cannot replace an entire school process performed over 10 years. Therefore, and in order to comply with Baquero's reasoning (1997), the development of rationale levels starts from the assimilation of experiences lived throughout the different cognitive stages of the person. In particular, the physical experience evaluates previous knowledge in order to readjust the cognitive structure, to incorporate new experiences and to achieve the goal of learning by organizing them into knowledge schemes that present different complexity levels.

Therefore, it is necessary that didactical learning strategies be implemented at the right time so that they can yield favorable results in academic groups. That is something that might have been a hindering factor in this investigation given that two months of work could have been not enough to see significant results in the groups.

Amongst the general issues, we can conclude that first semester students from the Colegio Mayor de Cundinamarca University (Technology in Architecture and Engineering De- 
sign program) showed low reasoning levels in the pre and post-test in the computer workshop class. That is something that can be caused by low quality and low frequency of previous intellectual stimulation. As a proof, $85.29 \%$ of the total number of students in the two groups is still at the concrete reasoning level while Richmond (1974), based on Piaget's theories, would classify this within the sub stage of concrete operations for the ages of 7 and 11 . This means that the group of students studied is still connected to an empirical reality with a preoperational thought where they have only achieved a limited amount of potential transformations.

In the teacher's practice, this investigation allowed us to determine that didactical learning strategies can be defined as the art of projecting, organizing and directing activities and internal classroom processes in order to achieve specific objectives. That development with the help of ICT's- allows the teacher, through the use of different technological tools, to guide certain cognitive operations in the students in order to facilitate the appropriation, organization and integration of the relevant information into their professional training.

The use of ICT's in the classroom must be conceived as a teaching-learning strategy that requires from teachers the comprehension of their students' surroundings. It is also required that teachers always help the students to use different digital tools as a support in their academic activities. That is all necessary to make it possible for the students to develop cognitive, social and reasoning skills. Ultimately, the strategic use of learning environments that use ICT's can make students strengthen their academic and professional practice as long as it is guided towards a functional context and applied to a coherent reality.

When comparing the reasoning of the students that used the PBL learning strategy and the CL learning strategy in two groups with the same academic characteristics, we can see that $85.29 \%$ of the total students in both groups are still at a concrete reasoning level. This means that they are still connected to an empirical reality with a pre-operational thought level and that they have achieved a limited amount of potential transformations that highlights an intellectual age between 7 and 11 years old. The results also suggest that students who participated in the PBL didactical strategy presented a minimal increase in their reasoning levels, increasing their formal and post-formal reasoning levels by $11.11 \%$ and $5.56 \%$, respectively. 
After the application of the didactical strategy in the $\mathrm{B}_{\mathrm{AC}}$ group, there was proof of a negative difference for the group. This means that there was proof of a setback in their reasoning and argument skills, which allows us to conclude that in the group projects it is crucial that the teacher gives his guidance constantly to the students so that they can appreciate the commitment both to their peers and towards the teacher. In this sense, it is pertinent to affirm that motivational and emotional variables play a key role in the development of cognitive skills, a flaw that was patent in the collaborative papers of group B. This could have generated a reduction in the student's compromise towards the development of activities. That is because even though the "main advantages derived from the use of collaborative learning strategies go to the student and the development of social interaction, meta-cognition and metaevaluation, which grants him more autonomy and pertinence in his participations" (Calzadilla, 2002, p. 9), this concept can be distorted and the students can assume it as a space to share personal experiences but not a space in which they develop academic processes, leaving development behind.

\section{References}

Barrows, H. S. (1986). Taxonomy of problem-based learning methods. Medical education, 20(6), 481-486. http://dx.doi.org/10.1111/j.1365-2923.1986.tb01386.x

Baquero, R. (1997). Vigotsky y el aprendizaje escolar (2nd ed). Argentina: Aique

Branda, L.A. (2013). "El abc del ABP-Lo esencial del aprendizaje basado en problemas". Quaderns de la Fundación Dr. Antoni Esteve, 27, 1-16. Retrieved from: http://www.raco.cat/index.php/QuadernsFDAE/article/view/278705

Calzadilla, M.E. (2002). “Aprendizaje colaborativo y tecnologías de la información y la comunicación. Revista Iberoamericana de educación, 1-10. Retrieved from: http://web.archive.org/web/20030314100158/http://www.campusoei.org/revista/deloslectores/322Calzadilla.pdf

Collazos, C.A, y Mendoza, J. (2006). “Cómo aprovechar el "aprendizaje colaborativo" en el aula". Educación y educadores, 9(2), 61-76. Retrieved from: http://www.scielo.org.co/pdf/eded/v9n2/v9n2a06.pdf

Colegio Mayor de Cundinamarca (2015) SIETIC. Retrieved from: http://sietic.unicolmayor.edu.co 
De la Vega, AG. (2010). "El aprendizaje basado en problemas como estrategia docente para una herramienta TIC en la didáctica de la geografía”. Retrieved from: http://www.agedidacticageografia.es/docs/Publicaciones/IVCongresoIberico/25.pdf

García de Cajén, S., García- Rodeja, E., \& Domínguez, JM. (2002). “Razonamiento y argumentación en ciencias”. In Enseñanza de las Ciencias, 20 (2), 217-228. Retrieved from: http://ddd.uab.cat/record/1561? ln=es

Giere, RN. (1994). "The cognitive structure of scientific theories". Philosophy of Science, 61(2), 276-296. Retrieved from: http://www.jstor.org/stable/188213

Gómez, B.R. (2005). “Aprendizaje basado en problemas (ABP): una innovación didáctica para la enseñanza universitaria”. Educación y educadores, 8, 9-19. Retrieved from: http://www.redalyc.org/articulo.oa?id=83400803

Guzmán, AL. (2014). Estudio de los factores que contribuyen al diseño de un plan estratégico para la incorporación de tecnologías de la información y la comunicación en una institución de educación preescolar básica y media bilingüe. (Master’s Thesis). University of La Sabana, Colombia. Retrieved from: http://hdl.handle.net/10818/15220

Lavigne, G., Vasconcelo, M. P., Organista, J., \& McAnally, L. (2012). “Exploración preliminar del aprendizaje colaborativo dentro un entorno virtual". Revista Actualidades Investigativas en Educación, 12(3), 1-20. http://dx.doi.org/10.15517/aie.v12i3.10295

Lawson, A.E. (1978). "The development and validation of a classroom test of formal reasoning”. Journal of Research in Science Teaching, 15(1), 11-24. http://dx.doi.org/10.1002/tea.3660150103

Lawson, A.E. (2008). "What can developmental theory contribute to elementary science instruction?" Journal of Elementary Science Education, 20(4), 1-14. Retrieved from: http://www.jstor.org/stable/43155833

Prieto, L. (2006). “Aprendizaje activo en el aula universitaria: el caso del aprendizaje basado en problemas". Miscelánea Comillas. Revista de Ciencias Humanas y Sociales 64(124), 173-196. Retrieved from: http://revistas.upcomillas.es/index.php/miscelaneacomillas/article/view/6558/6367

Martínez, M., Català, P., y Díaz, M. I. (2013). “Aprender colaborando: estrategias de aprendizaje colaborativo integradas en el aula universitaria". XI Jornadas de redes de investigación en docencia universitaria, (p.p 229- 242) Alicante, Spain: Alicante University. 
Morales, P. \& Landa, V. (2004). “Aprendizaje basado en problemas, problem-based learning”. Theoria, 13(1), 145-157. Retrieved from: http://www.ubiobio.cl/theoria/v/v13/13.pdf

Miguez, M. (2005). “El núcleo de una estrategia didáctica universitaria: motivación y comprensión”. Revista ieRed: Revista Electrónica de la Red de Investigación Educativa, 1(3), 1. Retrieved from: http://revista.iered.org/v1n3/pdf/mmiguez.pdf

Peña, J. (1993). “Comprensión y razonamiento: el enfoque cognitivo". Ideas y Valores, 42(90-91), 75-106. Retrieved from: http://www.bdigital.unal.edu.co/21902/1/1843759782-1-PB.pdf

Rapanta, C., Garcia-Mila, M., \& Gilabert, S. (2013). "What is meant by argumentative competence? An integrative review of methods of analysis and assessment in education". Review of Educational Research, 83(4), 483-520. https://doi.org/10.3102/0034654313487606

Raviolo, A., Siracusa, P., Herbel, M., and Schnersch, A. (2000). "Desarrollo de razonamientos científicos en la formación inicial de los maestros". Revista interuniversitaria de formación del profesorado, (38), 129-140. Retrieved from: http://www.aufop.com/aufop/uploaded_files/articulos/1223493229.pdf

Richmond, P. (1974). Introducción a Piaget (Vol. 1). Madrid, España: Editorial Fundamentos. Scagnoli, N. I. (2005). "Estrategias para motivar el aprendizaje colaborativo en cursos a distancia". Ideals. The Illinois Digital Environment for Access to Learning and Scholarship, pp. 1-15. Retrieved from: http://hdl.handle.net/2142/10681

Simon, S., Erduran, S., and Osborne, J. (2006). "Learning to teach argumentation: Research and development in the science classroom". International Journal of Science Education, 28(2-3), 235-260. http://dx.doi.org/10.1080/09500690500336957

Tarazona, JL. (2005). "Reflexiones acerca del aprendizaje basado en problemas (ABP). Una alternativa en la educación médica”. Revista colombiana de Obstetricia y Ginecología, 56(2), 147-154. Retrieved from: http://www.scielo.org.co/pdf/rcog/v56n2/v56n2a06

Thoron, A.C, Myers, B.E. (2012). Effects of Inquiry-based Agriscience Instruction on Student Scientific Reasoning. Journal of Agricultural Education, 53(4), 156-170. http://www.jae-online.org/index.php/back-issues/179-volume-53-number-4/1705effects-of-inquirybased-agriscience-instruction-on-student-scientific-reasoning

Vence, L. (undated). "Uso pedagógico de las TIC para el fortalecimiento de estrategias didácticas del programa todos a aprender". Ministerio de Educación Nacional. Retrieved from: http://www.mineducacion.gov.co/cvn/1665/articles-336355_archivo_pdf.pdf 